Arab Univ. J. Agric. Sci., Ain Shams Univ., Cairo, 13(2), 537 - 548, 2005

\title{
INSECTICIDAL ACTIVITY AND BIOCHEMICAL STUDIES OF EGYPTIAN SESBAN, SESBANIA aegyptica; JYNIT. SEED EXTRACTS AGAINST RICE WEEVIL, SITOPHILUS oryzae $\mathrm{L}$.
}

\author{
Salwa M.S. Ahmed ${ }^{1}$ and Nadra H. Al-Moajel ${ }^{2}$
}

\begin{abstract}
The toxic effective of wheat grains treated with Egyptian sesban, Sesbania aegyptica seed extracts offered to rice weevil, Sitophilus oryzae was determined. Chloroform extract was found to be the most effective. Reproductive potential of treated weevil were strongly affected as number of laid eggs was reduced and no progeny were obtained when adults were fed on wheat grains treated with either $\mathrm{Lc}_{\mathbf{5 0}}$ or $\mathrm{Lc}_{\mathbf{9 5}}$. Extracts treatment with $\mathrm{Lc}_{95}$ of extracts gave protection up to 10 weeks for petroleum ether, and 9 weeks for both chloroform and acetone extracts. All tested extracts reduced grain germination at the end of 14 weeks storage period. Treated wheat grains with Egyptian Sesban seed extracts reduced the weight loss of grains infested with the rice weevil. Biochemical studies show that some enzymes were affected in treated insects. S. aegyptica acetone extract was more effective than the other extracts, in this affect, as it caused a significant reduction in amylase, trehalse and acid phosphatase activity. However, this extract caused an increase in invertase, alkaline phosphatase and cholinestrase activity.
\end{abstract}

Key words: Egyptian sesbane, Rice weevil

\section{INTRODUCTION}

Stored grains are subject to attack by many insect species of which, if not adequately controlled, might cause serious economic damage. The use of insecticides causes many problems, such as harmful residues in the chain of food, pollution of environment, and disruption of biological balance by the destruction of the natural enemies.
The use of plant or their extracts exhibiting an insecticidal or insecticide synergistic activity against several insect species have been widely reported, (e.g. Makanijuola 1989, Afifi et al 1989; Jilani \& Su, 1983 and Ahmed 2001).

The rice weevil, Sitophilus oryzae. (Coleoptera : Curculionidae) is an insect of economic importance as it infests stored products causing a damage in the grains.

1- Plant Protection Res. Inst., Agric. Research Center, Dokki, Giza, Egypt.

2- Girls College, Riyadh, Saudi Arabia . 
The present work was conducted to evaluate the bioactivity of Sesbania aegyptica ; Jynit (Egyptian sesban) seed extracts on the rice weevil, Sitophilus oryzae L. Also, several researchers showed that some enzymes in several insect species were inhibited or activated by feeding them on a diet treated with plant extract, (AbouelGhar, et al 1994 and Rizvi et al 2001).

For this reason, some enzymes in adult weevils were estimated to clarify if they were effected in treated insects.

\section{MATERIAL AND METHODS}

\section{Insect culture}

The rice weevil, S.oryzae L. (Coleoptera : Curculionidae) were obtained from a well established laboratory culture maintained at the Stored Grains Insects, Research Division, Plant Protection Research Institute. Rearing of the insects was conducted under laboratory condition of $27 \pm 1{ }^{\circ} \mathrm{C}$ and $65 \pm 5 \%$ R.H., insects were offered wheat grains.

\section{Preparation of Sesbania aegyptica seed extract}

Egyptian sesban seeds more obtained from sesban trees planted in Giza Governorate. The seeds were washed thoroughly with water and dried. Dry seeds were ground to fine powder by a high speed micromill. The ground powder was extracted first with pet-ether (40-60) in a flask and left for 48 hours, the extract was then filtered and the solvent was evaporated under pressure by using a rotary evaporator. The detatted powder was thoroughly dried before being extracted next with chloroform, then acetone solvent, as adopted from Afifi et al (1988).

\section{Evaluation of $S$. aegyptica seed extract toxicity}

Toxicity of the three organic extracts was determined by adding different concentrations ranging from 2.0 to $5.0 \mathrm{ml} / \mathrm{kg}$, 0.50 to $2.00 \mathrm{ml} / \mathrm{kg}$ and 2.0 to $7.0 \mathrm{ml} / \mathrm{kg}$ for pet-ether, chloroform and acetone, respectively, to gm. of wheat grains.

Twenty five, 1-2 weeks old $S$. oryzae adults, obtained from the maintained stock culture were placed on the treated wheat grains, placed in glass tubes, the tubes were covered with muslin fixed with rubber band. Acetone was prepared containing untreated wheat grains. After $3,5,7$ and 14 days the tubes were investigated and the number of live and dead weevils counted. Accumulated mortality percentages $\mathrm{Lc}_{50}$ or $\mathrm{Lc}_{95}$ and regression line were determined and corrected by Abbott's formula, (1925), calculated according to Finney, (1952).

\section{Effect of $S$. aegyptica seed extracts on reproduction of $S$, oryzae}

Twenty $S$. oryzae 1-2 weeks old adults placed in glass tubes each containing $10 \mathrm{~g}$. wheat grains treated with each of the determined at $\mathrm{Lc}_{50}$ and $\mathrm{Lc}_{95} S$. aegyptica seed organic extract.

After two weeks, the tubes were opened and the insects removed. The number of deposited eggs, on the grains were counted according to the methods described by Frankenfeld, (1948) and Howe, (1952).

The same previous experiment was replicated, but laid eggs were left undisturbed to hatch. After two weeks the weevils were removed and the tubes left for seven weeks, up to $F_{1}$ adult progeny 
emergence. The number of emerged $F_{1}$ adults offspring were counted.

All of the forementioned experiments were replicated three times and a control containing untreated wheat included each time.

\section{Residual activity of $S$. aegyptica seed extracts on wheat grains}

Tubes containing $10 \mathrm{~g}$. of wheat grains treated with the determined $\mathrm{Lc}_{95}$ concentration of each extract, were divided into several groups.

Twenty five adults of $S$. oryzae were introduced into every three tubes at a weekly interval and up to 12 weeks. Similar three replicates of untreated wheat were used as control. In all cases, mortality percentages were corrected with Abbott's formula (1925).

\section{Effect of Egyptian sesban seed extracts on germination}

Germination of seeds treated with sesban seed extracts at the determined $\mathrm{Lc}_{95}$ 's of each of the three organic extracts was calculated at the initial time and at the end of 12 weeks storage period according to the International rules of seed testing (Anonymous, 1966).

Weight loss of wheat treated with $S$. aegyptica seed extract

Weight loss of wheat grains treated with Egyptian sesban seed organic extracts and infested with $S$. oryzae was determined according to the equation reported by Khare and Johari (1984):

$$
\text { Weight loss } \%=\frac{\begin{array}{c}
\text { Initial dry weight - } \\
\text { Final dry weight }
\end{array}}{\text { Initial dry weight }}
$$

Effect of sesban seed organic extracts on the activity of some enzymes of the rice weevil, $S$. oryzae

One-two weeks old $S$. oryzae weevils were offered wheat grains treated with $\mathrm{Lc}_{50}$ of sesban seed pet-ether, chloroform and acetone extracts. After 48 hours of feeding the insects were removed and a weight of $0.2 \mathrm{~g}$. of these weevils were homogenized in buffer solution. This solution was there filtered and the enzymatic activity were determined in the supernatant.

The following enzymes were considered:

\section{1- Carbohydrate enzymes : amylase, trehalase and invertase}

The method of Ishaaya and Swiriski (1976) was adopted. This method was based on the digection of starch and sugar by amylase, trehalase and invertase, respectively, using spectrometer $(550 \mathrm{~nm})$.

\section{2-Acid and Alkaline Poshatases}

These two enzymes were determined by measuring the optical density of the produced colour as described by Powell and Smith (1954), using spectrophotometer, $(510 \mathrm{~nm})$.

\section{3-Acetylcholine esterase (AchE)}

This enzyme was determined according to method described by Simpson et al (1964), where the optical density was 
measured spectrophotometrically at 515 nm.

\section{RESULTS AND DISCUSSION}

\section{Toxicity of Egyptian sesban seed ex- tracts on $S$. oryzae}

Sesban seed organic extracts at 4.0, 4.5 and $5 \mathrm{ml} / \mathrm{kg}$ for pet-ether, $0.75,1.0$ and $2.0 \mathrm{ml} / \mathrm{kg}$ for chloroform and 4.0, 5.0 and $7.0 \mathrm{ml} / \mathrm{kg}$ for acetone gave $100 \%$ mortality after 7 days for $S$. oryzae fed on treated wheat grains (Table, 1). $\mathrm{Lc}_{50}$ of seed organic extracts on the rice weevil was $3.5,0.8$, and $3.3 \mathrm{ml} / \mathrm{kg}$, when petether, chloroform and acetone, respectively were used in seed extraction (Table, 2). Meanwhile, $\mathrm{Lc}_{95}$ was 9.2, 1.3 and $10.0 \mathrm{ml} / \mathrm{kg}$ for the respective mentioned solvents. Values of slopes showed that the rate of acetone extract effectiveness was the lowest, meanwhile chloroform extract the highest.

Effect of sesban seed extract on egg fecundity and $\mathrm{F}_{1}$ progeny of $S$. oryzae

Wheat grains treated with $S$. aegyptica organic extracts and offered to $S$. oryzae weevils reduced their fecundity as well as number of $F_{1}$ adult emerged progeny (Table, 3). At $\mathrm{Lc}_{50}$ level, S. aegyptica acetone extract proved to be the most effective in this respect, as the number of laid eggs by 5 couples were 2.66 eggs as compared to 97.66 eggs in the control, equal to $96 \%$ reduction. Also, no $\mathrm{F}_{1}$ progeny were obtained. This was followed by pet-ether extract as 5.33 eggs per 5 females were recorded, i.e. $94 \%$ reduction. Meanwhile, chloroform seed extract was found to be the least effective, as it caused $82 \%$ reduction in egg fecundity and $75 \%$ in $\mathrm{F}_{1}$ progeny.
At $\mathrm{Lc}_{95}$ level, no eggs were laid when either acetone or pet-ether, either were used as solvent for sesban seed extraction and only 6.6 eggs by 5 females were recorded when chloroform was used (Table, $3)$.

\section{Residual effect of of $S$. aegyptica seed extracts on wheat grains offered to $S$. oryzae weevil}

The residual toxic effect of $S$. aegyptica seed extracts at $\mathrm{Lc}_{95}$ level (Table, 4) showed that the effect of these extracts was relatively stable up to $8^{\text {th }}$ weeks of storage. Soon after treatment mortality of weevils ranged between $95-96 \%$ and was only reduced between $94-95$ after $8^{\text {th }}$ week. By the $10^{\text {th }}$ week the toxic effect of $S$. aegyptica seed extracts to $S$. oryzae deteriorated slightly to reach 88 and $70 \%$

After 12 weeks of grain storage, mortality percentage of $S$. oryzae was only 30,37 and $45 \%$ for $S$. aegyptica acetone, pet-ether or chloroform extracts, denoting the ineffectiveness of these extracts past the $9^{\text {th }}$ week of storage.

\section{Effect of S. aegyptica extracts on ger- minate of treated wheat grains}

The germination of wheat grains soon after treatment was slightly reduced following treatment with $\mathrm{Lc}_{95}$ of $S$. aegyptica seed extracts. This effect was more apparent when pet-ether was used as solvent for extraction, followed by acetone then chloroform i.e 87,88 and $90 \%$ respectively. Meanwhile after 12 weeks of storage of treated wheat grains, germination was 82,84 and $86 \%$ for acetone and pet-ether and chloroform, respectively (Table, 5). In this respect, Shemais and Al-Moajel, (2000) found that wheat 
Table 1. Mortality percentages of $S$. oryzae fed on wheat grains treated with $S$. aegypti$c a$ seed extracts

\begin{tabular}{|ccccccc|}
\hline \multirow{2}{*}{\begin{tabular}{c} 
Solvent used for $\begin{array}{c}\text { Concentrations } \\
\text { treatment } \\
\text { ml/kg }\end{array}$ \\
\cline { 3 - 6 }
\end{tabular}} & \multicolumn{5}{c|}{ Mortality percentage after period (days) } \\
\hline \multirow{3}{*}{ Petroleum ether } & 2.0 & $00 \pm 0.00$ & $20 \pm 1.53$ & $39 \pm 4.05$ & $57 \pm 2.57$ & $86 \pm 3.06$ \\
& 3.0 & $00 \pm 0.00$ & $40 \pm 0.37$ & $68 \pm 4.17$ & $80 \pm 4.59$ & $98 \pm 1.16$ \\
& 4.0 & $8 \pm 1.53$ & $45 \pm 5.52$ & $100 \pm 0.00$ & $100 \pm 0.00$ & $100 \pm 0.00$ \\
& 4.5 & $12 \pm 0.8$ & $60 \pm 4.51$ & $100 \pm 0.00$ & $100 \pm 0.00$ & $100 \pm 0.00$ \\
& 5.0 & $20 \pm 1.16$ & $85 \pm 2.31$ & $100 \pm 0.00$ & $100 \pm 0.00$ & $100 \pm 0.00$ \\
\hline \multirow{3}{*}{ Chloroform } & 0.50 & $00 \pm 0.00$ & $20 \pm 3.06$ & $41 \pm 1.16$ & $62 \pm 0.58$ & $92 \pm 2.31$ \\
& 0.75 & $3 \pm 1.16$ & $50 \pm 1.00$ & $63 \pm 2.23$ & $100 \pm 0.00$ & $100 \pm 0.00$ \\
& 1.00 & $6 \pm 1.53$ & $80 \pm 3.06$ & $100 \pm 0.00$ & $100 \pm 0.00$ & $100 \pm 0.00$ \\
& 2.00 & $10 \pm 1.16$ & $90 \pm 4.17$ & $100 \pm 0.00$ & $100 \pm 0.00$ & $100 \pm 0.00$ \\
\hline \multirow{3}{*}{ Acetone } & 2.0 & $00 \pm 0.00$ & $28 \pm 1.53$ & $36 \pm 4.05$ & $54 \pm 2.31$ & $82 \pm 0.00$ \\
& 3.0 & $00 \pm 0.00$ & $35 \pm 2.52$ & $50 \pm 3.61$ & $79 \pm 3.06$ & $100 \pm 0.00$ \\
& 4.0 & $10 \pm 1.53$ & $65 \pm 3.52$ & $88 \pm 3.41$ & $100 \pm 0.00$ & $100 \pm 0.00$ \\
& 5.0 & $10 \pm 0.85$ & $70 \pm 3.51$ & $100 \pm 0.00$ & $100 \pm 0.00$ & $100 \pm 0.00$ \\
& 6.0 & $14 \pm 2.00$ & $80 \pm 3.06$ & $100 \pm 0.00$ & $100 \pm 0.00$ & $100 \pm 0.00$ \\
& 7.0 & $20 \pm 2.52$ & $90 \pm 2.52$ & $100 \pm 0.00$ & $100 \pm 0.00$ & $100 \pm 0.00$ \\
\hline
\end{tabular}

\pm Mean standard error

Table 2. $\mathrm{Lc}_{50}$ and $\mathrm{Lc}_{95}$ values and slopes of regression line for tested extracts against Sitophilus oryzae

\begin{tabular}{|lccc|}
\hline \multicolumn{1}{|c}{ Solvents } & $\mathrm{Lc}_{50}(\mathrm{ml} / \mathrm{kg})$ & $\mathrm{Lc}_{95}(\mathrm{ml} / \mathrm{kg})$ & Slopes \\
\hline Petroleum ether & 3.5 & 9.2 & 3.91 \\
Chloroform & 0.8 & 1.3 & 9.07 \\
Acetone & 3.3 & 10.0 & 3.38 \\
\hline
\end{tabular}

Arab Univ. J. Agric. Sci., 13(2), 2005 
Table 3. Fecundity and F1 progeny of Sitophilus oryzae fed on wheat grains treated with S. aegyptica extract

\begin{tabular}{|c|c|c|c|c|c|}
\hline Solvent & $\begin{array}{c}\text { Concentration } \\
\mathrm{ml} / \mathrm{kg}\end{array}$ & $\begin{array}{l}\text { Mean no. } \\
\text { of eggs } / 5 \\
\text { pairs }\end{array}$ & $\begin{array}{c}\text { (\%) Reduction } \\
\text { of } \\
\text { fecundity }\end{array}$ & $\begin{array}{l}\text { Mean of adult } \\
\text { progeny } \\
\text { emergence }\end{array}$ & $\begin{array}{l}\text { (\%) Reduction } \\
\mathrm{F}_{1} \text { adult } \\
\text { progeny }\end{array}$ \\
\hline $\begin{array}{l}\text { Petroleum } \\
\text { ether }\end{array}$ & $\begin{array}{c}\mathrm{Lc}_{50}(3.5) \\
\mathrm{Lc}_{95}(9.2) \\
\text { Control }\end{array}$ & $\begin{array}{c}5.33 \pm 1.2 \\
0.00 \pm 0.00 \\
97.33 \pm 3.67\end{array}$ & $\begin{array}{c}94 \\
100\end{array}$ & $\begin{array}{c}3.0 \pm 0.58 \\
0.00 \pm 0.00 \\
30.0 \pm 1.16\end{array}$ & $\begin{array}{c}90 \\
100\end{array}$ \\
\hline Chloroform & $\begin{array}{c}\mathrm{Lc}_{50}(0.8) \\
\mathrm{Lc}_{95}(1.3) \\
\text { Control }\end{array}$ & $\begin{array}{c}17.00 \pm 1.00 \\
6.66 \pm 2.07 \\
97.66 \pm 3.6\end{array}$ & $\begin{array}{l}82 \\
93\end{array}$ & $\begin{array}{c}9.33 \pm 0.43 \\
0.00 \pm 0.00 \\
38.33 \pm 3.18\end{array}$ & $\begin{array}{c}75 \\
100\end{array}$ \\
\hline Acetone & $\begin{array}{c}\mathrm{Lc}_{50}(3.3) \\
\mathrm{Lc}_{95}(10.0) \\
\text { Control } \\
--\end{array}$ & $\begin{array}{c}2.66 \pm 0.66 \\
0.00 \pm 0.00 \\
97.66 \pm 3.67\end{array}$ & $\begin{array}{c}96 \\
100\end{array}$ & $\begin{array}{c}0.00 \pm 0.00 \\
0.00 \pm 0.00 \\
26.00 \pm 2.08\end{array}$ & $\begin{array}{l}100 \\
100\end{array}$ \\
\hline
\end{tabular}

\pm Mean standard error

Table 4. Mortality percentages of Sitophilus oryzae fed on wheat treated with $\mathrm{Lc}_{95}$ of $S$. aegyptica seed extracts

\begin{tabular}{|cccc|}
\hline \multirow{2}{*}{ Weeks } & \multicolumn{3}{c|}{ Mortality percentage of S. oryzae weevils } \\
\cline { 2 - 4 } & Petroleum ether & Chloroform & Acetone \\
\hline Initial & $96 \pm 1.56$ & $95 \pm 0.00$ & $96 \pm 0.58$ \\
1 & $96 \pm 0.00$ & $96 \pm 1.16$ & $95 \pm 0.00$ \\
2 & $95 \pm 0.58$ & $96 \pm 1.53$ & $95 \pm 0.58$ \\
3 & $94 \pm 2.00$ & $96 \pm 2.00$ & $95 \pm 1.00$ \\
4 & $95 \pm 1.53$ & $95 \pm 0.58$ & $94 \pm 0.58$ \\
5 & $95 \pm 0.00$ & $95 \pm 5.20$ & $95 \pm 0.00$ \\
6 & $96 \pm 0.58$ & $94 \pm 1.53$ & $94 \pm 1.16$ \\
7 & $94 \pm 1.57$ & $95 \pm 0.00$ & $95 \pm 1.16$ \\
8 & $95 \pm 0.58$ & $94 \pm 2.00$ & $94 \pm 0.00$ \\
9 & $93 \pm 1.23$ & $95 \pm 1.53$ & $90 \pm 0.58$ \\
10 & $90 \pm 0.00$ & $88 \pm 0.58$ & $70 \pm 4.00$ \\
11 & $72 \pm 4.05$ & $62 \pm 2.08$ & $69 \pm 3.52$ \\
12 & $37 \pm 2.52$ & $45 \pm 0.00$ & $30 \pm 0.00$ \\
\hline
\end{tabular}

\pm Mean standard error

Arab Univ. J. Agric. Sci., 13(2), 2005 
grains treated with capparis seed extract lost viability especially at the end of storage.

\section{Weight loss of wheat grains treated with $S$. aegyptica extracts}

Wheat grains treated with $S$. aegyptica seed extracts caused a weight loss ranging between $62.75-66 \%$ in wheat grain weight than the control when treated at $\mathrm{Lc}_{50}$ level. Meanwhile, when treated with $\mathrm{Lc}_{95}$ this loss was between $91.95-99.99 \%$ than the control. Treated with pet-ether extract gave the most efficiency, meanwhile, chloroform extract the lowest effect (Table, 6). These results agree with Abdel-Latif, (2003), which found that treatment the cowpea and chickpea seeds with some natural oils reduced the weight loss in the seed.

Effect of tested extract on activity of some enzymes

\section{1- Amylase, Trehalase and Invertase}

The results exhibited in (Table, 7) show that there was a significant decrease in amylase activity in $S$. oryzae fed on $S$. aegyptica extracts at $\mathrm{Lc}_{50}$ level. The highest reduction in this enzyme activity was induced after treatment with chloroform extract, followed by pet-ether then acetone extracts (1255.39, 1309.66 and $1328.25 \mathrm{mg}$ glucose $/ \mathrm{min} / \mathrm{ml}$ ) respectively, compared to $1813.12 \mathrm{mg}$ glucose $/ \mathrm{min} / \mathrm{ml}$ in the control. These results are in agree with Ayyangar and Rao, (1990) who reported that digestive enzymes activity was reduced in $6^{\text {th }}$ instar larvae of $S$. littoralis injected with azadirachtin.
Also, there was a significant decrease in trehalase activity, the highest reduction was recorded after treatment with acetone extract followed by pet-ether (56.54 and $103.3 \mathrm{mg}$ glucose $/ \mathrm{min} / \mathrm{ml}$ respectively). On the other hand chloroform extract caused a significant increase in trehalase activity (198.31 $\mathrm{mg}$ glucose/min/ml) compared to untreated insects $(128.32 \mathrm{mg}$ glucose $/ \mathrm{min} / \mathrm{ml}$ ). Similarly, Abou ElGhar et al (1994) found that acetone extract of Melia azedrach caused an increase in trehalase activity of A. ipsilon larvae.

On the other hand, all the tested extracts caused an insignificant increase in invertase activity. Acetone extract caused the highest increase (486.39 $\mathrm{mg}$ glucose $/ \mathrm{min} / \mathrm{ml}$ ) followed by pet-ether and chloroform extracts (476.24 and 468.44 $\mathrm{mg}$ glucose $/ \mathrm{min} / \mathrm{ml}$ respectively), compared the control insects (418.84 $\mathrm{mg}$ glucose $/ \mathrm{min} / \mathrm{ml}$ ). El-Skeikh (2002) found an increase in trehalase activity after treating $6^{\text {th }}$ instar larvae of $A$. ipsilon with acetone extract of Melia azedrach seeds.

\section{2- Phosphatase activity}

Data in (Table, 8) revealed that Egyptian sesban seed extracts decreased acid phosphatase activity in treated weevils. Acetone extract, caused the lowest decrease followed by pet-ether and then chloroform (170.66, 195.83 and 198.31 $\mathrm{mg}$ phosphate $/ \mathrm{min} / \mathrm{ml}$, respectively) compared to $248.76 \mathrm{mg}$ phosphate/min/ $\mathrm{ml}$ in untreated insects.

Acetone extract caused a significant increase in alkaline phosphatase activity. Meanwhile, pet-ether and chloroform caused an insignificant decrease. Imtiaz, (2001) reported a decrease in alkaline 
Table 5. Germination of wheat grains stored for 12 weeks after treatment with S. aegyptica seed extracts

\begin{tabular}{|lccccc|}
\hline \multirow{2}{*}{ Solvent } & $\begin{array}{c}\text { Concentration } \\
\text { ml/kg }\end{array}$ & \multicolumn{2}{c}{ Initial time } & \multicolumn{2}{c|}{ After 12 weeks storage } \\
\cline { 3 - 6 } & & $\begin{array}{c}\text { Germination } \\
(\%)\end{array}$ & $\begin{array}{c}\text { Reduction } \\
\%\end{array}$ & $\begin{array}{c}\text { Germination } \\
(\%)\end{array}$ & $\begin{array}{c}\text { Reduction } \\
\%\end{array}$ \\
\hline Petroleum ether & 9.2 & $87 \pm 1.16$ & 9.38 & $84 \pm 1.00$ & 11.58 \\
Chloroform & 1.3 & $90 \pm 1.53$ & 6.25 & $86 \pm 1.73$ & 19.47 \\
Acetone & 10.0 & $88 \pm 0.33$ & 8.33 & $82 \pm 1.16$ & 13.68 \\
\hline Control & & $96 \pm 0.58$ & & $95 \pm 1.53$ & \\
\hline
\end{tabular}

Table 6. Effect of tested extracts on grains weight loss

\begin{tabular}{|cccc|}
\hline Solvent & $\begin{array}{c}\text { Concentration } \\
\mathrm{ml} / \mathrm{kg}\end{array}$ & $\begin{array}{c}\text { Dry weight loss } \\
\%\end{array}$ & $\begin{array}{c}\text { Dry weight reduction } \\
\%\end{array}$ \\
\hline \multirow{3}{*}{ Petroleum ether } & $\mathrm{Lc}_{50}(3.5)$ & 1.90 & 66 \\
& $\mathrm{Lc}_{95}(9.2)$ & 0.0004 & 99.99 \\
& $\mathrm{Con}$ trol & 2.98 & \\
& & 1.11 & 62.75 \\
Chloroform & $\mathrm{Lc}_{50}(0.8)$ & 0.24 & 91.95 \\
& $\mathrm{Lc}_{95}(1.3)$ & 2.98 & 65.44 \\
& $\mathrm{Control}^{*}$ & 1.03 & 92.28 \\
\hline & $\mathrm{Lc} c_{50}(3.3)$ & 0.23 & \\
\hline
\end{tabular}


Table 7. Activity of S. oryzae digestive enzymes treated with S. aegyptica extracts

\begin{tabular}{|c|c|c|c|c|c|c|}
\hline \multirow[b]{3}{*}{ Solvents } & \multicolumn{6}{|c|}{ Digestive enzymes (mg glucose/min/ml) } \\
\hline & \multicolumn{2}{|c|}{ Amylase } & \multicolumn{2}{|c|}{ Trehalase } & \multicolumn{2}{|c|}{ Invertase } \\
\hline & Activity & $\begin{array}{c}\text { Change } \\
\text { in } \\
\text { percentage } \\
\%\end{array}$ & Activity & $\begin{array}{c}\text { Change } \\
\text { in } \\
\text { percentage } \\
\%\end{array}$ & Activity & $\begin{array}{c}\text { Change } \\
\text { in } \\
\text { percentage } \\
\%\end{array}$ \\
\hline $\begin{array}{c}\text { Petroleum } \\
\text { ether }\end{array}$ & $\begin{array}{c}1309.66 \pm \\
22.00\end{array}$ & -27.76 & $\begin{array}{c}103.39 \pm \\
5.80\end{array}$ & -19.43 & $\begin{array}{c}476.24 \pm \\
11.78\end{array}$ & +13.70 \\
\hline Chloroform & $\begin{array}{c}1255.39 \pm \\
55.28\end{array}$ & -30.76 & $\begin{array}{c}198.31 \pm \\
12.23\end{array}$ & +54.54 & $\begin{array}{c}468.44 \pm \\
15.54\end{array}$ & +11.84 \\
\hline Acetone & $\begin{array}{c}1328.25 \pm \\
38.46\end{array}$ & -26.74 & $\begin{array}{c}56.54 \pm \\
4.67\end{array}$ & -55.94 & $\begin{array}{c}486.39 \pm \\
9.79\end{array}$ & +16.36 \\
\hline Control & $\begin{array}{c}1813.12 \pm \\
87.12\end{array}$ & & $\begin{array}{c}128.32 \pm \\
7.61\end{array}$ & & $\begin{array}{c}418.86 \pm \\
10.33\end{array}$ & \\
\hline
\end{tabular}

\pm mean standard deviations

-Inhibition

+Activation

Table 8. Activity of phosphatase enzymes and acetylecholine estrase in S. oryzae treated with $S$. aegyptica seed extracts

\begin{tabular}{|c|c|c|c|c|c|c|}
\hline \multirow[b]{3}{*}{ Solvent } & \multicolumn{4}{|c|}{ Phosphatase (mg phosphate/min/ml) } & \multirow{2}{*}{\multicolumn{2}{|c|}{$\begin{array}{l}\text { Acetylecholine esterase } \\
\text { (m acetylcholine } / \mathrm{min} / \mathrm{ml})\end{array}$}} \\
\hline & \multicolumn{2}{|c|}{ Acid } & \multicolumn{2}{|c|}{ Alkaline } & & \\
\hline & Activity & $\begin{array}{c}\text { Change } \\
\text { in } \\
\text { percentage } \\
\%\end{array}$ & Activity & $\begin{array}{c}\text { Change } \\
\text { in } \\
\text { percentage } \\
\%\end{array}$ & Activity & $\begin{array}{c}\text { Change } \\
\text { in } \\
\text { percentage } \\
\%\end{array}$ \\
\hline $\begin{array}{l}\text { Petroleum } \\
\text { ether }\end{array}$ & $\begin{array}{c}195.83 \pm \\
6.27\end{array}$ & -21.28 & $\begin{array}{l}4.11 \pm \\
0.24\end{array}$ & -32.40 & $\begin{array}{c}1465.66 \pm \\
46.70\end{array}$ & +19.19 \\
\hline Chloroform & $\begin{array}{c}198.31 \pm \\
12.23\end{array}$ & -20.28 & $\begin{array}{l}5.35 \pm \\
0.45\end{array}$ & -12.01 & $\begin{array}{c}1248.90 \pm \\
33.44\end{array}$ & +1.57 \\
\hline Acetone & $\begin{array}{c}170.66 \pm \\
5.56\end{array}$ & -31.40 & $\begin{array}{c}11.64 \pm \\
1.050\end{array}$ & +91.45 & $\begin{array}{c}1445.13 \pm \\
47.95\end{array}$ & +17.61 \\
\hline Control & $\begin{array}{c}248.76 \pm \\
9.42\end{array}$ & & $\begin{array}{l}6.08 \pm \\
0.85\end{array}$ & & $\begin{array}{c}1229.65 \pm \\
31.11\end{array}$ & \\
\hline
\end{tabular}

\pm mean standard deviations

-Inhibition

+Activation

Arab Univ. J. Agric. Sci., 13(2), 2005 
phosphatase activity in $S$. oryzae treated with neem leaf extract.

\section{3-Choline esterase activity}

Data in (Table, 8) revealed that both acetone and pet-ether extracts significantly increased the activity of choline esterase enzyme however, meanwhile, extract caused an insignificant increase. Rizivi $\boldsymbol{e t}$ $\boldsymbol{a l}$ (2001), found an inhibition in the choline esterase activity in Tribolium castaneum after treatment with Clerodenreem inerme leaf extract.

\section{REFERENCES}

Abbott W.S. (1925). A method of computing the effectiveness of an insecticide. J. Econ. Entomol: 18(2): 265-276.

Abdel latif, A.M. (2003). Effect of some plant oils as protectant of stored legumes against cowpea beetle, Callosobruchus maculatus (F.) infestation. Fayoum $J$. Agric., Res. \& Dev., 17)(2): 98-106.

Abou El-Ghar, G.E.S.; H.S. Radwan; Z.A. El-Bermay and L.T.M. Zidan, (1994). Histopathological effects of abamection and difubenzuron on the midgut of Spodotera littoralis (Lepidoptera: Noctuidae) larvae. Bull. Entomol Soc. Egypt, Econ. Ser. 21: 41-52.

Afifi, F.A.; A.M. Hekal and M. Salem (1988). Fenugreek seed extracts as protectant of wheat grains against certain stored product insects. Annals Agric. Sci. Fac. Agric., Ain Shams Univ., Cairo, Egypt, 33(2): 1331-1344.

Afifi, F.A. Salem and A.M. Hekal (1989). Insecticidal properties of the extracts of lupin seed and caraway fruits against some stored products insects. $A n$ nals Agric. Sci., Fac. Agric. Ain Shams Univ. Cairo, Egypt, 34(1): 401 - 414.
Ahmed, Salwa, M.S. (2001). Lupin seed (Lupinus termis) extracts as grain protectants against the rice weevil (Sitophilus oryzae L.) and the lesser grain borer (Rhizopertha dominical F.), Egypt. J. Agric. Res., 79(1): 89-103.

Anonymous, (1966). International rules for seed testing. Proc. Internat. Seed Testing Associations, 31: 49 - 91.

Ayyangar, G.S.G. and P.J. Rao (1990). Azadirachtin effects on consumption and utilization of food and midgut enzymes of Spodotera litura (Fabr.). Ind. J. Entomol., 51: 373-376.

Finney. D.F. (1952). Probit Analysis. pp. 135-156. Cambridge University press, London.

Frankenfeld, J.C. (1948). Statining methods for detecting weevil infestation in grains. U.S.A. Entomol, Bur., El-256, p. 4.

Howe, R.W. (1952). The biology of the rice weevil Sitophilus oryzae. Ann. App. Biol. 39(2): 168-180.

Imtiaz-Ahmed, M.A.; Farzana-Shuja; M.A. Azmi; Kahkashan - Anktar; S.A. Rizvi; Muzaffer-Ahmad (ed.) and A.R. Shakoori, (2001). Comparative toxicological studies of neem leaf extract and cyhalothrin (pyrethroid) against Sitophilus oryzae and their effects on alkaline phosphatase activity. Proceeding of Pakistan Confress of Zoology. 21: 255-261

Ishaaya, I. and E. Swirski, (1976). Trehalase, invertase and amylase activities in the black scale saissetia oleae and their relation for host adaptability. J. Insect Physiol. 22: 1025-1029.

Jilani, G. and H.C.F. Su, (1983). Laboratory studies on several plant materials as insect repellents for protection of cereal grains. J. Econ. Entomol., 76: 154-157. 
Khare, B.P. and R.K. Johari, (1984). Influence of phenotypic characters of chickpea (Cicer arietinum L.) cultivars on their susceptibility to Callosobruchus chinenss L.) Legume Res., 7(1): 54-56.

Makonjoula, W.A. (1989). Evaluation of extracts of neem (Azadirachta indica AJuss) for control of some stored products insects. J. Stored Prod. Res., 25(4): 231237.

Powell, M.E.A. and M.J.H. Smith, (1954). The determination of serum acid and alkaline phosphatase activity with 4 amino antipyrine. J. Clin. Pathol., 7: 245 -248 .

Rizivi, S.A.; A. Ayaz-Ahmed; M.A. Imitaz-Ahmed; Kahkashan-Akhtar; Muzaffer-Ahmad (ed.) and A.R. Shakoori, (2001). Determination of tox- icity of clerodendrum inerme and cypermethion against Tribolum castanum and their effects on acid phosphatase and cholinesterase enzymes. Proceeding of Pakistan Confress of Zoology. 21: 175-180. Shemais Sawsan A. and Nadra H. AlMoajel (2000). Efficiency and persistence of extracted capparis, Cappris spinosa seeds against the rice weevil Sitophilus oryzae L. (Curculionidae : Coleoptera). Egypt. J. Appl. Sci., 15(2): 267274.

Simpson, D.R.; D.L. Bull and D.A. Lindquist, (1964). A semimicro technique for the estimation of cholinesterase activity in boll weevil. Ann. Entomol. Soc. Am., 57(3): 367-377. 
بحلة اتحاد الجامعات العربية للدراسات والبحوث الزراعية ، جامعة عين شمس ، القاهرة ، 13(2) ، 537 - 548 ، 2005

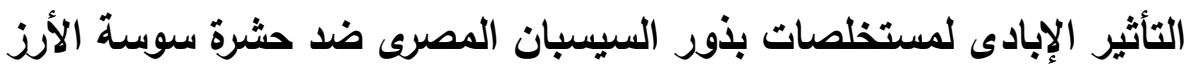
ويعض الاراسات البيوكيميائية للحشرة

$[35]$

\section{سلوى مصطفى سبد احمد 1 - نادرة حمود المعجل2 2}

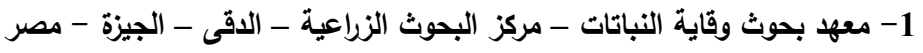
2- كلية التربية للبنات - الأقسام العلمية - الرياض - المملكة العربية السعودية النيات النيات

تـأثر الإنبـات فـى بدايـة التخـزين حيـث

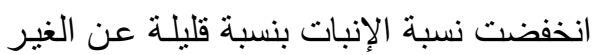

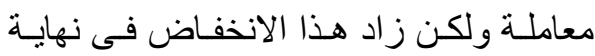
فترة التخزين . معامل ولين الحبـوب المعاملـــة بــالتركيزين القـاتلين

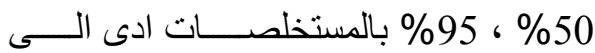
انخفاض الفقد فى الوزن مقارنة بالغير معامل

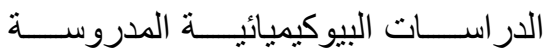

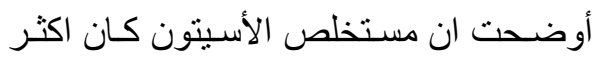

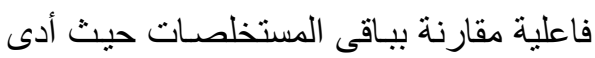

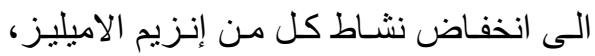

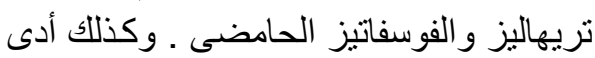

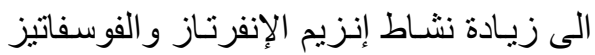

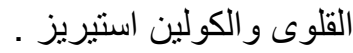

تــم تقــدير تـأثنير معاملــة حبـوب القـــح

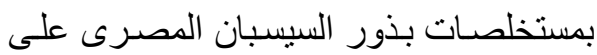
حشرة سوسة الأرز وكذلك تم تقدير التركيز

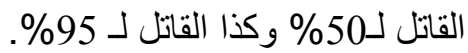
مستخلص الكلوروفورم كـان اكثر كفاءة الفـل

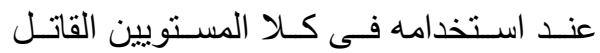
. \%95 ، \50

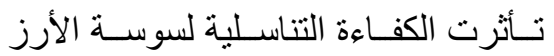
تأثر ا شديداً وخصوصا عند استخدام التركيز

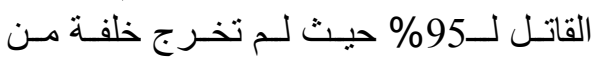
الحبوب المعاملة . معاملة الحبوب بالتركيز القاتل لـ 95\%

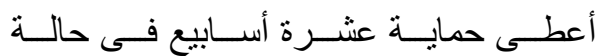

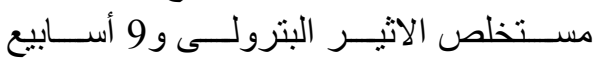

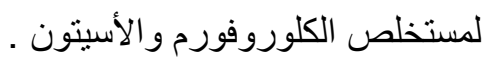

$$
\text { تحكيم: أ.د فايزة مرعى أحمد مرعى أ.د سناء محمـود محجوب }
$$

